\author{
Robert Tyrata \\ Uniwersytet Papieski Jana Pawta II w Krakowie \\ Akademia Muzyczna w Krakowie \\ Międzynarodowa Federacja Pueri Cantores
}

\title{
Muzyka liturgiczna w przeżyciu Misterium Paschalnego ${ }^{1}$
}

16 stycznia 1988 roku watykańska Kongregacją Kultu Bożego wydała list okólny O przygotowaniu i obchodzeniu świąt Paschalnych. Precyzuje on wiele kwestii dotyczących sposobów obchodzenia tych najważniejszych dni w życiu Kościoła, tak od strony liturgii, a w niej muzyki, jak też przy zwróceniu uwagi na tradycje i zwyczaje obecne w krajach świata. W interesującym nas więc okresie liturgicznym mowa jest o szczególnych wydarzeniach. List precyzuje to w następujący sposób:

największe misteria ludzkiego odkupienia sprawuje Kościół co roku począwszy od mszy wieczornej Wielkiego Czwartku, aż do nieszporów Niedzieli zmartwychwstania. Czas ten słusznie jest określany jako „Triduum Chrystusa ukrzyżowanego, pogrzebanego i wskrzeszonego ${ }^{2}$.

Sama nazwa „Triduum Paschalne” pojawiła się w 1929 roku i upowszechniła się od czasu reform liturgicznych podjętych już przez papieża Piusa XII. Wyrażenia „Triduum” nie można tłumaczyć jako „trzy dni”, nie chodzi tu przecież o wyliczanie godzin. Są to szczególne trzy fazy, niejako: uczta pożegnalna i zarazem prorocza ofiary krzyżowej, śmierć na krzyżu, spoczynek w grobie i zmartwych-

1 Wystąpienie miało miejsce podczas XXXVI Congreso Nacional de Muscia Liturgica 24-28 II 2014, Monterrey, Mexico.

2 List okólny Kongregacji Kultu Bożego Paschalis sollemnitatis. O przygotowaniu i obchodzeniu świąt Paschalnych, 38 [dalej skrót LO]; tł. na j. polski: „Kielecki Przegląd Diecezjalny” 64 (1988) 4, s. 229-243; Congregatio pro Culto Divino, Letterae circulares Paschalis sollemnitatis. De festis paschalibus praeparandis et celebrandi, (16 I 1988): tekst łac. „Notitiae” 24 (1988), s. 81-107. Przekład pol. „Ruch Biblijny i Liturgiczny” 5 (1988), s. 369-391. 
wstanie. W historii takie celebracje zakorzeniły się w liturgii jerozolimskiej. Opis szczegółowy Triduum odnaleźć można już w Pamiętniku pątniczki Egerii³

\section{Ważność muzyki w ogóle w obrzędach Triduum Paschalnego}

Dosyć istotne miejsce w watykańskim dokumencie zajmuje przypomnienie, że w czasie Triduum odprawiana uroczyście (śpiewana) ma być poranna modlitwa Kościoła.

Zaleca się wspólne sprawowanie Godziny Czytań i Jutrzni w Wielki Piątek Męki Pańskiej i w Wielką Sobotę. Wypada, aby w tej modlitwie w kościele katedralnym uczestniczył biskup, o ile to możliwe, razem z duchowieństwem i ludem ${ }^{4}$.

Bardzo istotne jest, by wszystkie modlitwy były śpiewane:

śpiew ludu, usługujących i kapłana celebrującego ma szczególne znaczenie w obrzędach Wielkiego Tygodnia, a zwłaszcza w ciągu Paschalnego Triduum, ponieważ bardzo odpowiada uroczystemu charakterowi tych dni, a także dlatego, że teksty najbardziej osiągają swoją wymowę wtedy, gdy są śpiewanes.

Dlatego też mocno się zachęca, aby konferencje episkopatów przygotowały melodie do tekstów i aklamacji. Chodzi tutaj zwłaszcza o: modlitwę powszechną w Wielki Piątek, śpiew na odsłonięcie krzyża, aklamacje w czasie procesji z paschałem, śpiew orędzia wielkanocnego, błogosławieństwa wody chrzcielnej. Zwraca się uwagę na ważność śpiewów procesyjnych, takich jak m.in.: śpiew na procesję z palmami, psalmy responsoryjne. Konieczne jest zwrócenie uwagi na przygotowanie melodii do śpiewanej Męki Pańskiej. ${ }^{6}$ Bardzo istotne jest także to, że: „W większych kościołach należy korzystać z bogatego skarbca muzyki sakralnej, tak starodawnej jak i współczesnej, zawsze jednak trzeba dbać o odpowiednie uczestnictwo ludu"’. Co więcej, list ten określa jednoznacznie, iż

3 Zob. B. Nadolski, Liturgika, t. 2, Liturgia i czas, Poznań 1991, s. 65.

4 LO 40.

5 LO 42.

6 Zob. LO 42.

7 LO 42. 
tam gdzie nie można zgromadzić wystarczającej liczby uczestników, ministrantów i śpiewaków, nie należy sprawować obrzędów Paschalnego Triduum, a wierni niech się razem zgromadzą w jakimś większym kościele 8 .

Po przedstawieniu znaczenia prawnego i teologicznego oraz liturgicznego przebiegu uwzględniającego muzykę liturgiczną pozwalam sobie odwołać się do konkretnych propozycji muzycznych, które stosujemy w katedrze królewskiej w Krakowie. Jest to praktyka wypracowywana od paru już lat.

\section{Msza Wieczerzy Pańskiej}

Liturgia Wieczerzy Pańskiej jest szczególnym momentem, w którym Kongregacja zwraca uwagę na ważność muzyki liturgicznej. Najpierw:

jeśli istnieje taki miejscowy zwyczaj, podczas śpiewu „Chwała na wysokości Bogu” uderza się w dzwony; po skończeniu tego śpiewu dzwony milkną aż do „Chwała na wysokości Bogu” w Wigilię Paschalną [...]. W tym samym czasie gra na organach i na innych instrumentach jest dozwolona tylko dla podtrzymania śpiewu?

Istnieje zwyczaj nieużywania jednak w ogóle w tym właśnie czasie dzwonów, dzwonków, muzyki organowej i pojawiają się tzw. kołatki.

Zwyczaj ten sięga czasów karolińskich. Amalary z Metzu upatrywał w nim znak naśladowania pokory w uniżeniu się Jezusa. Tkwi w nim także nawiązanie do czasów, kiedy w liturgii nie używano dzwonów czy instrumentów ${ }^{10}$.

Można też mówić o swoistym „poście dla uszu”. Dalej zwraca się uwagę, że na procesję z darami ofiarnymi winno się śpiewać pieśn Gdzie mitość wzajemna i do$b r o c^{11}$. W tradycji śpiew ten związany był z obrzędem umywania nóg uczniom, tzw. mandatum, bowiem był ten śpiew wykonywany przy wydawaniu żywności ${ }^{12}$. Kolejnym śpiewem, który wymienia list, jest śpiew na procesję do ołtarza

\footnotetext{
8 LO 43.

9 LO 50.

${ }^{10}$ B. Nadolski, Liturgika, dz. cyt., s. 67.

${ }^{11}$ LO 52.

12 Zob. B. Nadolski, Liturgika, dz. cyt., s. 66.
} 
przechowywania Najświętszego Sakramentu po zakończonej liturgii. Dokument stwierdza, że wówczas wykonuje się śpiew Staw, języku, tajemnicę ${ }^{13}$.

Antyfona na wejście przedstawia się następująco: „Chlubimy się krzyżem naszego Pana Jezusa Chrystusa; w nim jest nasze zbawienie, życie i zmartwychwstanie, przez niego jesteśmy zbawieni i oswobodzeni” (Ga 6,14), dlatego też na rozpoczęcie liturgii proponuję śpiew z wiernymi o Krzyżu pt. Krzyżu święty, nade wszystko drzewo ${ }^{14}$, następnie zaś motet śpiewany przez chór: In monte Oliveti Mikołaja Zieleńskiego. Podczas umywania nóg śpiewamy z wiernymi pieśń Gdzie mitość wzajemna jest i dobroć, a następnie chór śpiewa hymn Maurice’a Duruflé Ubi Caritas et Amor. Jeśli jeszcze istnieje potrzeba, śpiewamy z wiernymi Przykazanie nowe daje wam ${ }^{15}$. Na przygotowanie darów ofiarnych chór śpiewa motet Tomasa Luisa da Victorii Jesu dulcis memoria, następnie z wiernymi śpiewamy pieśń $Z$ rąk kaptańskich przyjmij, Panie ${ }^{16}$. Ponieważ antyfona na komunię

${ }^{13}$ LO 54.

${ }^{14}$ Cztery pierwsze zwrotki są tłumaczeniem fragmentu hymnu Venanzio Fortunata z VI wieku Pange, lingua („Pange lingua, gloriosi Lauream [proelium] certaminis”) (zwracam uwagę, że początkowe słowa mogą mylić z hymnem św. Tomasza, stąd podaję dłuższe brzmienie); w polskiej tradycji w użyciu są tekst i muzyka pochodzące z XVI wieku. Pieśń obecna jest w Śpiewniku kościelnym ks. Michała M. Mioduszewskiego CM (Kraków 1838). Tekst pieśni: „Krzyżu święty, nade wszystko drzewo przenajszlachetniejsze! / W żadnym lesie takie nie jest, jedno, na którym sam Bóg jest / Słodkie drzewo, słodkie gwoździe, Rozkoszny Owoc nosiło / Skłoń gałązki drzewo święte, ulżyj członkom tak rozpiętym! / Odmień teraz oną srogość, którąś miało z przyrodzenia / Spuść lekuchno i cichuchno Ciało Króla Niebieskiego. / Tyś samo było dostojne nosić światowe zbawienie / Przez cię przewóz jest naprawion, światu, który był zagubion, / Który święta Krew polała, co z Baranka wypływała / Niesłychana to jest dobroć za kogo na krzyżu umrzeć”.

${ }^{15}$ Pieśń: Przykazanie nowe daje wam - tekst refrenu to J 13, 34, tekst zwrotek to 1 Kor 13. Muzykę do refrenu napisała Zofia Jasnota, muzykę do zwrotek ks. Zdzisław Bernat. Pieśń pojawia się w Śpiewniku kościelnym ks. Jana Siedleckiego z 1973 roku. Tekst pieśni przedstawia się następująco: „Ref. Przykazanie nowe daję wam, byście się wzajemnie miłowali; Gdybym mówił językami ludzi i aniołów, a miłości bym nie miał, stałbym się jak miedź brzęcząca albo cymbał brzmiący / Gdybym posiadał wszystką wiedzę i wiarę taką, iżbym góry przenosił, lecz miłości bym nie miał, byłbym niczym / I gdybym rozdał ubogim całą swoją majętność, a ciało swe wystawił na spalenie, lecz miłości bym nie miał, nic mi nie pomoże / Miłość jest cierpliwa, miłość jest łaskawa. Miłość nie zazdrości, nie szuka poklasku / Miłość nie unosi się pychą, ale jest pokorna / Miłość nie szuka swego, gniewem się nie unosi. Miłość nie pamięta złego, nie cieszy się z niesprawiedliwości, lecz współweseli się z prawdą”.

${ }^{16}$ Jest to część tzw. pieśni mszalnych, czyli pieśni tłumaczących poszczególne części mszy świętej. Całość pieśni nosi tytuł Boże, lud Twój, w pierwotnym układzie była to piąta z kolei zwrotka pieśni śpiewanej do jednej melodii, różne zaś zwrotki były przeznaczone na: 1. Wejście, 2. Gloria, 3. Ewangelia, 4. Credo, 5. Offertorium itd. Autorem tekstu jest Hen- 
przedstawia się następująco: „To jest Ciało moje za was wydane; * ten kielich jest Nowym Przymierzem we Krwi mojej. * Czyńcie to, ile razy spożywać będziecie, * na moją pamiątkę" (1 Kor 11, 24. 25), dlatego też rozpoczynamy ten obrzęd pieśnią z wiernymi $O$, Krwi najdroższa ${ }^{17}$. Następnie chór śpiewa motet Gioachino Rossiniego $O$ salutaris Hostia. Jeśli istnieje taka potrzeba, śpiewamy następnie z wiernymi pieśn Pan wieczernik przygotowat ${ }^{18}$. Podczas przeniesienia Najświętszego Sakramentu do kaplicy adoracji chór śpiewa pieśń Adorote devote w opracowaniu wielogłosowym, później wierni śpiewają pieśń Staw, języku, tajemnicę. Całość modlitwy kończy chór, śpiewając motet Josepha Haydna Tristis est anima mea.

\section{Liturgia Męki Pańskiej}

Jest to szczególny dzień, gdy „zgodnie z najdawniejszą tradycją Kościół nie sprawuje w tym dniu Eucharystii" ${ }^{19}$. Gdy pojawi się konieczność odprawienia w tym dniu pogrzebu chrześcijańskiego, należy go sprawować bez śpiewu, bez gry na organach i dźwięku dzwonów ${ }^{20}$. Ważnym momentem liturgii jest odsłonięcie

ryk Felsztyński. Tekst wydrukowano w śpiewniku: Tomasz Kunzek, Pieśni kościelne, Lwów 1859, zaś melodia pojawia się w Śpiewniczku zawierajacym pieśni kościelne ks. Jana Siedleckiego (Kraków 1895). Oto tekst 2 zwrotki na przygotowanie darów ofiarnych: „Z rąk kapłańskich przyjmij, Panie, tę ofiarę chleba, wina, co się wkrótce dla nas stanie Krwią i Ciałem Twego Syna / Niech przestępstwa nasze zmywa i uśmierza gniew Twój, Panie. Niech nas z niebem pojednywa i uzyska przebłaganie".

${ }^{17}$ Pieśń O Krwi najdroższa, o Krwi odkupienia - tekst tej pieśni pojawia się w Śpiewniczku Eucharystycznym (Lwów 1884), melodia zaś w Śpiewniczku zawierającym pieśni kościelne ks. Jana Siedleckiego (Kraków 1908). Tekst pieśni jest następujący: „O Krwi najdroższa, o Krwi odkupienia, / napoju życia, z nieba dla nas dany! / O zdroju łaski, o ceno zbawienia, / Ty grzechowe leczysz rany! / Tyś w Jezusowym kielichu zamknięta, / abyś nas wszystkich życiem napawała, / abyś dla świata, Krwi Boska prześwięta, / miłosierdzie wybłagała!”.

${ }^{18}$ Pieśń Pan Wieczernik przygotowat - tekst ułożyła s. M. Imelda Kosmala CSSF, zaś melodię ułożył Tomasz Kiesewetter. Pieśń pojawia się w Śpiewniku kościelnym ks. Jana Siedleckiego (Kraków 1987). Tekst pieśni przedstawia się: „Ref. Pan Wieczernik przygotował, swój zaprasza lud. / Dla nas wszystkich dom otworzył i zastawił stół. / Przyjdźcie, z ulic i opłotków, bowiem mija czas. / Przyjdźcie, chorzy i ubodzy, Pan uzdrowi was. / Każdy człowiek w domu Pańskim swoje miejsce ma. / Niech nikogo w nim nie braknie, uczta Pańska trwa. / Przystępujmy z dziękczynieniem, pożywajmy chleb, / pijmy napój nieśmiertelnych, aby życie mieć. / Zakosztujcie i poznajcie tej wieczerzy smak, / z obfitości Boskich darów bierzcie pełnię łask".

${ }^{19}$ LO 59.

${ }^{20}$ LO 61. 
i adoracja krzyża. Kongregacja zwraca na niego szczególną uwagę. „Obrzęd ten należy sprawować z okazałością godną tego znaku naszego zbawienia: zarówno wezwania przy odsłonięciu Krzyża, jak i odpowiedź ludu winny być śpiewane"21. A także dalej precyzuje: „podczas adoracji Krzyża niech będą wykonywane antyfony, «Improperia» i hymny, które w sposób liryczny przywołują na pamięć historię zbawienia, albo inne stosowne pieśni”22. Ukazanie krzyża w tradycji Kościoła zostało ubogacone także takimi elementami jak: antyfona Crucem Tuam z IX wieku, która była śpiewana od XI wieku po łacinie i grecku pod wpływem liturgii bizantyńskiej. Kolejny śpiew to Trishagion wspomniany przez sobór w Chalcedonie (451 rok), który jako aklamacja wszedł do liturgii w V-VI wieku, a także wspomniane już w watykańskim dokumencie improperia. Są to oskarżenia ludu, które wypowiada Jezus; ludu, który nie dostrzegł dzieł Boga poprzez życie i mękę Chrystusa. W historii znane są dwa rodzaje improperiów. Jest to mianowicie: Ludu mój, ludu połączone z Trishagionem i Ego te et tu. W XV-wiecznych mszałach te dwa typy zostały połączone. Ich tłumaczenia na język polski to wspaniałe pod względem literackim teksty. Św. Tomasz z Akwinu napisał zaś pieśń Pange lingua gloriosi, która została złączona z obrzędem adoracji krzyża. Zaznacza się także bardzo wyraźnie w liście Kongregacji Kultu Bożego, że po adoracji krzyża kapłan celebrujący śpiewa wezwanie do Modlitwy Pańskiej, którą następnie śpiewają wszyscy ${ }^{23}$. Nie może tu być więc mowy o recytacji. Śpiew jest więc szczególniejszą modlitwą. Bardzo ważne jest także przywołanie tradycji ludowej poszczególnych Kościołów lokalnych:

z racji duszpasterskich nigdy nie należy zaniedbywać w tym dniu nabożeństw, jak Droga Krzyżowa, procesja ku czci Męki Pańskiej i wspomnienie boleści Najświętszej Maryi Panny. Teksty i śpiewy tych nabożeństw należy dostosować do ducha liturgii ${ }^{24}$.

W wawelskiej katedrze muzyka liturgiczna podczas liturgii Męki Pańskiej przedstawia się następująco: tekst Męki Pańskiej jest śpiewany na uroczystą melodię przez trzech kantorów. Wezwania do modlitwy powszechnej podaje, śpiewając, diakon. Przy adoracji krzyża rozpoczyna chór Improperia Giovanniego Pierluigiego da Palestriny. Po ich zakończeniu chór śpiewa antyfonę Crucem Tuam nieznanego kompozytora. Następnie rozpoczyna się śpiew wiernych,

\footnotetext{
${ }^{21} \mathrm{LO} 68$.

${ }^{22}$ LO 69.

${ }^{23}$ Zob. LO 70.

${ }^{24} \mathrm{LO} 72$.
} 
którzy podejmują pod przewodnictwem scholi kleryków następujące śpiewy (wszystkie o tematyce pasyjnej): W krzyżu cierpienie ${ }^{25}$ oraz Krzyżu Chrystusa, bądżże pochwalony ${ }^{26}$. Następnie chór katedralny śpiewa Miserere Gregorio Allegriego. Podczas przyjmowania komunii św. przez wiernych prowadzenie śpiewu rozpoczyna zwykle chór katedralny, śpiewając antyfonę Christus factus est pro nobis, następnie wierni śpiewają O Krwi Najdroższa $a^{27}$. Na dziękczynienie wszyscy wierni śpiewają bardzo popularną pieśń w Kościele w Polsce Duszo Chrystusowa, uświęć mnie $e^{28}$. Podczas przeniesienia Najświętszego Sakramentu do kaplicy wystawienia, zwanej także w Polsce „grobem bożym”, chór śpiewa motet ks. Grzegorza Gerwazego Gorczyckiego Sepulto Domino. Następnie wier-

${ }^{25}$ Pieśń W krzyżu cierpienie - autorem tekstu jest ks. Karol Antoniewicz SJ, melodia pojawia się w Śpiewniczku zawierającym pieśni kościelne ks. Jana Siedleckiego (Kraków 1895). Tekst pieśni jest następujący: „W krzyżu cierpienie, w krzyżu zbawienie, w krzyżu miłości nauka. / Kto Ciebie, Boże, raz pojąć może, ten nic nie pragnie, ni szuka. / W krzyżu osłoda, w krzyżu ochłoda, dla duszy smutkiem zmroczonej. / Kto krzyż odgadnie, ten nie upadnie w boleści sercu zadanej / Kiedy cierpienie, kiedy zwątpienie serce ci na wskroś przepali, / gdy grom się zbliża, pospiesz do krzyża. On ciebie wesprze, ocali / Gdy cię skrzywdzono albo zraniono lub serce czyjeś zawiodło / o nie rozpaczaj, módl się, przebaczaj, / krzyż niech ci stanie za godło".

${ }^{26}$ Pieśń Krzyżu Chrystusa, bądźże pochwalony - tekst i melodia tej pieśni pojawia się w Śpiewniku kościelnym ks. Jana Siedleckiego z 1959 roku. Wierni śpiewają następujące słowa w pieśni: „Krzyżu Chrystusa, bądźże pochwalony. / Na wieczne czasy bądźże pozdrowiony, / gdzie Bóg, Król świata całego / dokonał życia swojego. Krzyżu Chrystusa, bądźże pochwalony. / Na wieczne czasy bądźże pozdrowiony! / Ta sama Krew Cię skropiła, / która nas z grzechów obmyła. / Krzyżu Chrystusa, bądźże pochwalony. / Na wieczne czasy bądźże pozdrowiony! / Z Ciebie moc płynie i męstwo, / w Tobie jest nasze zwycięstwo".

${ }^{27}$ Pieśń O Krwi najdroższa - tekst tej pieśni pojawia się w Śpiewniczku Eucharystycznym, Lwów 1884, melodia zaś w Śpiewniczku zawierającym pieśni kościelne ks. Jana Siedleckiego (Kraków 1908). Tekst pieśni jest następujący: „O Krwi najdroższa, o Krwi odkupienia, / napoju życia, z nieba dla nas dany! / O zdroju łaski, o ceno zbawienia, / Ty grzechowe leczysz rany! / Tyś w Jezusowym kielichu zamknięta, / abyś nas wszystkich życiem napawała, / abyś dla świata, Krwi Boska prześwięta, / miłosierdzie wybłagała! / O Krwi najdroższa, przez serce przeczyste, / gdzie Twoje źródło miałaś na tej ziemi, / cześć Tobie niesiem, dzięki wiekuiste / z aniołami, ze świętymi”.

${ }^{28}$ Pieśń Duszo Chrystusowa - tekst jest tłumaczeniem modlitwy św. Ignacego Loyoli Anima Christi z XVI wieku. Melodia autorstwa Stefana Stuligrosza pojawia się Śpiewniku kościelnym ks. Jana Siedleckiego 1973 roku. Tekst śpiewu przedstawia się: „Duszo Chrystusowa, uświęć mnie. / Ciało Chrystusowe, zbaw mnie. / Krwi Chrystusowa, napój mnie. / Wodo z boku Chrystusowego, obmyj mnie. / Męko Chrystusowa, pokrzep mnie. / O dobry Jezu, wysłuchaj mnie: / w ranach swoich ukryj mnie, / nie dopuść mi oddalić się od Ciebie, / od złego ducha broń mnie. / W godzinę śmierci wezwij mnie / i każ mi przyjść do siebie, / abym z świętymi Twymi chwalił Cię / na wieki wieków. Amen”. 
ni śpiewają wierni Jezu Chryste Panie mity ${ }^{29}$. Prowadzenie modlitwy przez śpiew kończy chór katedralny, który wykonuje motet Jacoba Handla Ecce Quomodo moritur iustus.

Już poza liturgią Męki Pańskiej śpiewane są w Polsce Gorzkie żale - to nabożeństwo powstałe w dawnej Polsce, a w XVIII wieku wydane drukiem i zatytułowane Snopek mirry ${ }^{30}$. Tekst i melodie ułożył ks. Wawrzyniec Benik CM w Warszawie w 1707 roku. Jest to modlitwa śpiewana rozpamiętująca mękę i śmierć Jezusa Chrystusa. W tradycji Kościoła w Polsce znajdziemy także duży zestaw pieśni pasyjnych, często o pochodzeniu ludowym, ale doskonale pomagających stworzyć klimat Wielkiego Piątku. Są one nie tylko elementem tradycji, ale chętnie śpiewane są i dzisiaj przez wiernych.

\section{Wigilia Paschalna}

Oczywiste jest, co podkreśla watykański dokument, iż:

wszystkie obrzędy Wigilii Paschalnej odbywają się w nocy: nie wolno ich rozpoczynać, zanim nie zapadnie noc, a należy je zakończyć przed świtem niedzieli. Zasada ta musi być interpretowana ściśle. Przeciwnie jej nadużycia i tu i ówdzie praktykowane zwyczaje sprawowania Wigilii Paschalnej o godzinie, w której zwykło się antycypować Mszę niedzielną, zasługują na odrzucenie ${ }^{31}$.

Najważniejszy śpiew owej liturgii to oczywiście Orędzie Paschalne, które opowiada o historii zbawienia ${ }^{32}$. Dialogowanie poprzez czytane lekcje z Pisma

${ }^{29}$ Pieśń Jezu Chryste, Panie mity - tekst autorstwa Abrahama Różniatowskiego z 1610 roku. Pojawia się wraz z melodią w Śpiewniku kościelnym ks. Michała M. Mioduszewskiego CM (Kraków 1838). Tekst pieśni napisany przez Abrahama Różniatowskiego w 1610 roku jest następujący: „Jezu Chryste, Panie miły, / o Baranku tak cierpliwy, wzniosłeś, wzniosłeś na krzyż ręce swoje, / gładząc, gładząc nieprawości moje. / Płacz Go, człowiecze mizerny, / patrząc, jak jest miłosierny. / Jezus, Jezus na krzyżu umiera, / słońce, słońce jasność swą zawiera. / Pan wyrzekł ostatnie słowa, / zwisła Mu na piersi głowa. / Matka, Matka pod Nim frasobliwa, / stoi, stoi z żalu ledwie żywa. / Na koniec Mu bok przebito, / krew płynie z wodą obfito. / Żal nasz, żal nasz dziś wyznajem łzami, / Jezu, Jezu, zmiłuj się nad nami”.

${ }^{30}$ Zob. W. Kałamarz, W poszukiwaniu pierwotnej melodii-najstarsze, śpiewnikowe wersje melodyczne „Gorzkich żali”, [w:] Perty muzyki kościelnej: chorat gregoriański i Gorzkie żale, red.

R. Tyrała, Kraków 2007, s. 94 (Pro Musica Sacra, 7).

${ }^{31}$ LO 78.

${ }^{32}$ Zob. LO 84. 
św. Starego i Nowego Testamentu, uzupełnione są poprzez śpiewy psalmów responsoryjnych ${ }^{33}$. Bardzo ważne - jak się wydaje - jest w tym temacie stwierdzenie, że „pilne trzeba czuwać nad tym, aby ludowe piosenki nie były wykonywane zamiast psalmów"34. Oczywiście zgodnie ze zwyczajem po czytaniach ze Starego Testamentu śpiewa się hymn Chwata na wysokości Bogu ${ }^{35}$, zaś po czytaniu z Nowego Testamentu następuje ważny moment liturgii ze względu na śpiew.

Kapłan trzy razy intonuje „Alleluja”, stopniowo podnosząc głos, lud zaś tę aklamację powtarza. Jeśli jest to konieczne, psałterzysta lub kantor wykonuje „Alleluja”, którą to aklamację podejmuje lud, powtarzając ją między wersetami Psalmu $117^{36}$.

Bardzo ważną częścią celebracji Wigilii Paschalnej jest liturgia chrzcielna. Gdy po poświęceniu wody chrzcielnej, odnowieniu przyrzeczeń chrzcielnych następuje pokropienie wiernych nową wodą święconą, wówczas wszyscy wierni powinni śpiewać antyfonę Vidi aquam lub inną pieśń o tematyce chrzcielnej ${ }^{37}$. Prawodawca zwraca uwagę, że następująca po wszystkim liturgia Eucharystii nie może być sprawowana w pośpiechu. Kapłan przewodniczący liturgii powinien posłużyć się modlitwą eucharystyczną pierwszą, drugą lub trzecią „z zastosowaniem śpiewu”38. Sugeruje się także w watykańskim dokumencie, że „na komunię wypada śpiewać psalm 117 z antyfoną "Nasza Pascha», lub psalm 33 z antyfoną "Alleluja, alleluja, alleluja», albo inny śpiew wyrażający paschalną radość"39. Liturgia Wigilii Paschalnej ma być sprawowana tak,

aby obdarzyła lud chrześcijański bogactwem modlitw i obrzędów, trzeba dlatego zadbać o prawdziwość rzeczy, o uczestnictwo wiernych oraz o to, aby w jej sprawowaniu nie brakowało ministranów, lektorów i scholi śpiewaków ${ }^{40}$.

\footnotetext{
${ }^{33}$ Zob. LO 85-86.

${ }^{34}$ LO 86.

${ }^{35}$ LO 87.

${ }^{36}$ LO 87.

${ }^{37}$ Zob. LO 89.

${ }^{38}$ LO 91.

${ }^{39}$ LO 91.

${ }^{40}$ LO 93.
} 
W katedrze na Wawelu podczas pokropienia wiernych śpiewamy starą polską pieśn Przez chrztu świętego wielki dar ${ }^{41}$. Następnie na procesję z darami śpiewa chór Alleluja, chwalcie Pana w Jego świątyni Michała Woźnego, a następnie wierni śpiewają Wstat Pan Chrystus ${ }^{42}$. Podczas procesji komunijnej chór śpiewa wielogłosowo antyfonę komunijną z Wigilii Paschalnej Wczesnym rankiem A. Griesbachera, po czym wierni śpiewają pieśń Nie zna śmierci Pan żywotd ${ }^{43}$. Podczas rezurekcyjnej procesji, która jest niesieniem Najświętszego Sakramentu z insygniami Chrystusa Zmartwychwstałego trzy raz wokół kościoła, gdy bije dzwon Zygmunt (z XVI wie$\mathrm{ku}$ ), śpiewamy przede wszystkim pieśni z wiernymi: Wesoty nam $d z i e n ́$ dziś nastat ${ }^{\mathbf{4} 4}$,

${ }^{41}$ Pieśń Przez Chrztu świętego wielki dar - tekst jest autorstwa I. Świdy, melodia Romana Dwornika. Pieśń pojawia się w śpiewniku Alleluja wydanym pod redakcją ks. Józefa Zawitkowskiego (Warszawa 1978). Tekst pieśni jest następujący: „Przez Chrztu świętego wielki dar, / o Chryste, z Twej hojności, / Twym dzieciom wiary dałeś skarb / nadziei i miłości. / Najświętszej Trójcy wieczną cześć / pragniemy z serc gorących nieść. / Strzec wiary ślubujemy, / w niej żyć, umierać chcemy. / Z wyznawców Twoich wiernych rzesz / swój Kościół tworzysz w świecie, / w Ojczyźnie naszej władasz też / przez długie tysiąclecie”.

${ }^{42}$ Pieśń Wstat Pan Chrystus - tekst Surrexit Christus hodie pochodzi z XIV wieku, polskie tłumaczenie z XVI wieku. Polski tekst z odmienną od używanej dzisiaj melodią obecny jest w Śpiewniku kościelnym ks. Michała M. Mioduszewskiego CM (Kraków 1838). Używana dziś melodia pojawia się w Śpiewniczku zawierającym pieśni kościelne ks. Jana Siedleckiego (Kraków 1878). Tekst pieśni przestawia się następująco: „Wstał Pan Chrystus z martwych ninie, Alleluja, Alleluja! / uweselił lud swój mile. Alleluja, Alleluja! / Nie żałował życia swego Alleluja, Alleluja! / dla człowieka mizernego. / Alleluja, Alleluja! Tego dnia wielkanocnego Alleluja, Alleluja! / chwalmy wraz Zmartwychwstałego. Alleluja, Alleluja! / Świętą Trójcę wyznawajmy, Alleluja, Alleluja! / Bogu cześć i chwałę dajmy. Alleluja, Alleluja!”.

${ }^{43}$ Pieśń Nie zna śmierci Pan żywota - tekst autorstwa Franciszka Karpińskiego z końca XVIII wieku. Używana dzisiaj melodia, określana jako krakowska, pojawia się w Śpiewniczku zawierającym pieśni kościelne ks. Jana Siedleckiego (Kraków 1895). Oto tekst pieśni: „Nie zna śmierci Pan żywota, chociaż przeszedł przez jej wrota. / Rozerwała grobu pęta ręka święta. Alleluja! / Twój, Adamie, dług spłacony, okup ludzki dokończony. / Wnijdziesz w niebo z szczęśliwymi dziećmi twymi. Alleluja! / Próżno, straże, grób strzeżecie, już Go tutaj nie znajdziecie. / Wstał, przeniknął skalne mury Bóg natury. Alleluja!”.

${ }^{44}$ Pieśń Wesoty nam dzień dziś nastat - tekst i melodia tej pieśni obecne są w Śpiewniku kościelnym ks. Michała M. Mioduszewskiego CM (Kraków 1838). Tekst jednak pochodzi z XVII wieku, zaś melodia z XVI wieku. Tekst pieśni jest następujący (początkowe zwrotki): „Wesoły nam dzień dziś nastał, / którego z nas każdy żądał, / tego dnia Chrystus zmartwychwstał. / Alleluja, alleluja! Król niebieski k’nam zawitał, / jako śliczny kwiat zakwitał, / po śmierci się nam pokazał. / Alleluja, alleluja! / Piekielne moce zwojował, / nieprzyjaciele podeptał, / nad nędznymi się zmiłował. / Alleluja, alleluja! / Do trzeciego dnia tam mieszkał, / ojce święte tam pocieszał, / potem iść za sobą kazał. / Alleluja, alleluja! / Którzy w otchłaniach mieszkali, / płaczliwie tam zawołali, / gdy Zbawiciela ujrzeli: / Alleluja, alleluja!". 
Zwycięzca śmierci ${ }^{45}$, Otrzyjcie już tzy, ptaczący ${ }^{46}$. Wszystkie one są o tematyce zmartwychwstania Pana Jezusa. Dochodząc do ołtarza po procesji (wokół katedry), śpiewamy uroczyste $T e$ Deum laudamus ${ }^{47}$, które śpiewa chór na zmianę z wiernymi. Po błogosławieństwie i słowie końcowym kardynała śpiewamy antyfonę Regina coeli laetare $^{48}$, a następnie chór śpiewa alleluja z II części oratorium Mesjasz Georga Friedricha Haendla.

\section{Dzień Wielkanocy}

W sam dzień Zmartwychwstania pojawia się drugi formularz mszy (już nie $\mathrm{z}$ wigilii, ale $\mathrm{z}$ dnia). Posiadane teksty tej mszy od $\mathrm{X}$ wieku rozbudowane były neumatycznie, a więc pojawiły się tropy i sekwencje. Po Soborze Trydenckim pozostała jedna sekwencja, do dzisiaj zresztą śpiewana Victimae paschali laudes. Jej autorem jest Vipo z Brugundii (zm. 1046) ${ }^{49}$.

Niedziela, jaką jest dzień Zmartwychwstania Pańskiego, winna być podkreślona przez dwa szczególne elementy liturgiczne. Chodzi mianowicie o zastoso-

${ }^{45}$ Pieśń Zwycięzca śmierci - tekst i melodia tej pieśni obecne są w Dodatku do Śpiewnika kościelnego ks. Michała M. Mioduszewskiego CM (Kraków 1842). Tekst pieśni przedstawia się następująco (początkowe zwrotki): „Zwycięzca śmierci, piekła i szatana / wychodzi z grobu dnia trzeciego z rana. / Naród niewierny trwoży się przestrasza / na cud Jonasza. Alleluja! / Ziemia się trzęsie, straż się grobu miesza, / anioł zstępuje, niewiasty pociesza: / „Patrzcie - tak mówi - / grób ten próżny został, / Pan z martwych powstał”. Alleluja! / Ustąpcie od nas smutki i trosk fale, / gdy Pan Zbawiciel triumfuje w chwale. / Ojcu swojemu już uczynił zadość, / nam niesie radość. Alleluja!”.

${ }^{46}$ Pieśń Otrzyjcie już tzy, ptaczący - tekst i melodia pojawiają się Śpiewniczku zawierającym pieśni kościelne ks. Jana Siedleckiego (Kraków 1878). Tekst pieśni Otrzyjcie już tzy, płaczqcy przestawia się następująco: „Otrzyjcie już łzy, płaczący, żale z serca wyzujcie, / wszyscy w Chrystusa wierzący, weselcie się, radujcie, / bo zmartwychwstał samowładnie, jak przepowiedział dokładnie. / Alleluja, alleluja, niechaj zabrzmi: «Alleluja»! / Darmo kamień wagi wielkiej Żydzi na grób wtoczyli, / darmo dla pewności wszelkiej zbrojnej straży użyli. / Na nic straż, pieczęć i skała nad grobem Pana się zdała. / Bóg wszechmocny, Bóg natury wyższy nad wszystkie twory. / Wstaje z grobu, kruszy mury, nie zna żadnej zapory. / Zdjęta trwogą straż upada i prawie sobą nie włada".

${ }^{47} \mathrm{Te}$ Deum laudamus - tekst pochodzi z IV wieku. Dziś autorstwo najczęściej przypisuje się Nicetasowi z Remezjany. W Polsce śpiewamy ten hymn w tłumaczeniu ks. Tadeusza Karyłowskiego SJ, do melodii ks. Antoniego Chlondowskiego SDB.

${ }^{48} \mathrm{~W}$ Polskiej tradycji występuje także wersja w języku polskim niezmiernie popularna i chętnie śpiewana przez wiernych antyfona Regina coeli laetare - tekst tej maryjnej antyfony pochodzi z okresu miedzy IX a XII wiekiem. Przypisywany bywa Grzegorzowi V (X wiek). Melodia pochodzi z XIII wieku, zaś obecna postać to jej XVII-wieczne opracowanie.

49 Zob. B. Nadolski, Liturgika, dz. cyt., s. 72. 
wanie w ramach obrzędu aktu pokutnego pokropienia wodą święconą. „Należy wtedy śpiewać antyfonę «Vidi aquam» lub inną pieśń o charakterze chrzcielnym”50. Drugim ważnym liturgicznym przeżyciem dnia Wielkanocy są wedle watykańskiego dokumentu „o przeżywaniu świąt paschalnych” nieszpory chrzcielne. Dokument stwierdza:

tam gdzie istnieje, należy zachować, a jeśli nie - wprowadzić tradycję sprawowania w dniu Paschy owych Nieszporów chrzcielnych, w których podczas śpiewu psalmów odbywa się procesja do chrzcielnicy ${ }^{51}$.

Od X wieku odprawiano te nieszpory z udziałem nowo ochrzczonych, którzy przy śpiewie psalmu 92 procesyjnie udawali się do chrzcielnicy.

Przy źródle chrzcielnym śpiewano Psalm 113 i Magnificat. Procesja kierowała się następnie do kaplicy Krzyża św. przy śpiewie Vidi aquam. Uczestnikom na koniec serwowano trzy gatunki wina w portykach kaplicy ${ }^{52}$.

\section{Streszczenie}

\section{Muzyka liturgiczna w przeżyciu Misterium Paschalnego}

Jeśli „muzyka jest integralną częścią uroczystej liturgii” (KL 112), to niezmiernie ważne jest, by podczas najważniejszych wydarzeń w świątyni, a zwłaszcza liturgicznych celebracji, stawała się ona czytelnym znakiem. Gdy bowiem przygotowujemy muzykę liturgiczną, zawsze zwracamy uwagę na: rok liturgiczny, a więc okres, uroczystość czy wspomnienie, zatrzymujemy się nad treścią antyfony mszalnej (w odniesieniu do pieśni na wejście i komunię), formularzem mszalnym, treścią kolekty i czytań mszalnych, zwłaszcza zaś Ewangelii. I ta cała treść przeżywanych liturgicznych modlitw i czytań ma znaleźć swoje odzwierciedlenie właśnie w muzyce, którą proponuje się na celebrację. Na tym właśnie polega jej integralność, że nie jest jakimś uzupełnieniem, dopełnieniem, zastąpieniem,

\footnotetext{
${ }^{50} \mathrm{LO} 97$.

${ }^{51}$ LO 98.

52 B. Nadolski, Liturgika, dz. cyt., 72.
} 
oprawą, ale jest tożsama z liturgią, jest z nią nierozerwalnie związana. Ona z niej wypływa i do niej prowadzi. Ona ją ubogaca, upiększa i jest bardziej czytelnym jej znakiem.

Nie inaczej ma być z muzyką podczas Triduum Paschalnego. Ta muzyka musi być jeszcze bardziej i lepiej przemyślana, bowiem tu mamy do czynienia z najważniejszym wydarzeniem całego roku liturgicznego jakim jest święto Chrystusa, cierpiącego, ukrzyżowanego i zmartwychwstałego. To jest najważniejsze wydarzenie zbawcze sprawowane tu i teraz. Na wielkie znaczenie i wymowę tych świętych dni Triduum Paschalnego zwrócił uwagę papież Benedykt XVI podczas audiencji generalnej 19 marca 2008. Niech słowa te będą szczególną konkluzją mojego wystąpienia. Ojciec święty powiedział:

te trzy dni są powszechnie nazywane „wielkimi”, ponieważ przeżywamy w nich na nowo najważniejsze wydarzenie naszego odkupienia. Przypominają nam bowiem o samej istocie wiary chrześcijańskiej - męce, śmierci i zmartwychwstaniu Jezusa Chrystusa. Te dni moglibyśmy potraktować jako jeden jedyny dzień: stanowią one serce i kulminacyjny moment całego roku liturgicznego oraz życia Kościoła. [...] Wspominać tajemnice Chrystusa znaczy również głęboko i solidarnie uczestniczyć w obecnie dokonującej się historii, z przekonaniem, że to, co celebrujemy, jest rzeczywistością żywą i aktualną [...]. Te dni budzą w nas wielką nadzieję: ukrzyżowany Chrystus zmartwychwstał i zwyciężył świat. Miłość jest silniejsza od nienawiści, odniosła zwycięstwo, a my powinniśmy uczestniczyć w tym zwycięstwie miłości. Powinniśmy więc zacząć na nowo od Chrystusa i pracować w jedności z Nim na rzecz świata, którego fundamentami są pokój, sprawiedliwość i miłośćc 53 .

\section{Summary}

\section{Muzyka liturgiczna w przeżyciu Misterium Paschalnego}

If "the music is an integral part of the solemn liturgy" (SC 112) it is tremendously important that during the crucial ceremonies at churches, particularly those involving liturgical celebrations, it would become its clear sign. Since, when we prepare liturgical music we always draw our special attention to: liturgical year, namely, to a particular season, feast or celebration, examining the contents of the holy mass antiphon (referring to entrance songs and the holy communion), the mass order, the collect and the readings,

53 Benedykt XVI, Udienza Generale, (19 03. 2008), www.vatican.va/holy_father/benedict_ xvi/audiences/2008/documents/hf_ben-xvi_aud_20080319_it.html (dostep: 15.02.2014). 
especially the Gospel. And this entire content of liturgical prayers and readings is to be reflected through music of the celebrations. Therefore the music becomes integral because its role is not merely supplementary, complementary, substitutive nor decorative, but incorporated in liturgy with which it is inextricably linked. Music springs from liturgy and leads to liturgy. It enriches mass liturgy, makes it more grandly and clearly rendered.

It should be no different during the Easter Triduum for which the music ought to be even more thoroughly prepared as for the most important season of the liturgical year, that is, the Feast of Christ, suffering, crucified and resurrected. As it is the greatest event of the mystery of redemption observed here and now. The importance of the Easter Triduum was indicated by Pope Benedict XVI during his General Audience on 19 March 2008. May his words serve as the conclusion of my speech:

These three days are commonly known as 'holy' because they allow us to re live the event central to our Redemption. They lead to nucleus of Christian faith: the passion, Heath, and resurrection of Jesus Christ. These three days could be considered as one single day. They make up the heart and are the key to both the liturgical year and the life of the Church. ... Remembering the mysteries of Christ also means a willing and complete adherence to the history of today, convinced that when we celebrate, it is vivid and present reality... These holy days reawaken a great hope in us: Christ was crucified, yet he rose again and conquered the world. Love is stronger than hate, it has triumphed and we should affiliate ourselves with this victory of love. We should therefore start again from Christ and work together with him for a world founded on peace, justice and love $e^{54}$.

Stowa kluczowe muzyka kościelna, Triduum Paschalne, śpiewy chóralne i wiernych podczas Triduum, msza Wieczerzy Pańskiej, Liturgia Męki Pańskiej, Wigilia Paschalna

Keywords liturgical music, Paschal Triduum, choir singing and lay brother's singing, Mass of the Lord's Supper, Liturgy of the Passion, Easter Vigil

\section{Bibliografia}

Benedykt XVI, Udienza Generale, (19 03. 2008), www.vatican.va/holy_father/benedict_ xvi/audiences/2008/documents/hf_ben-xvi_aud_20080319_it.html

${ }^{54}$ Benedict XVI, Udienza Generale, (19 03. 2008) www.vatican.va/holy_father/benedict_xvi/ audiences/2008/documents/hf_benxvi_aud_20080319_it.html (dostęp: 15.02.2014). 
Congregatio pro Culto Divino, Letterae circulares Paschalis sollemnitatis. De festis paschalibus praeparandis et celebrandi (16 I 1988), „Notitiae” 24 (1988), s. 81-107.

Kongregacja Kultu Bożego, List okólny O przygotowaniu i obchodzeniu świąt Paschalnych, tł. na j. polski: „Kielecki Przegląd Diecezjalny”, 64 (1988) 4, s. 229-243.

Nadolski B., Liturgika, t. 2, Liturgia i czas, Poznań 1991. 